Moscow refusniks suffer over Nature letter to scientific union

\section{London}

A GROUP of Moscow refusniks who pubished a letter recently in Nature (324, 204 ; 1986) report reprisals from the KGB and Public Prosecutor's Office. The letter was addressed to Professor Jean-Marie Legay, president of the World Federation of Scientific Workers (WFSW), and two of the signatories, Dr Alexander Ioffe and Dr Boris Klotz, had tried to deliver it to Legay personally last July, during the SFSW General Assembly in Moscow. They were, however, prevented by plainclothes men from meeting Legay in his hotel, although he had agreed to a meeting. Unable to arrange another meeting, they decided to convey their message to Legay through the columns of Nature.

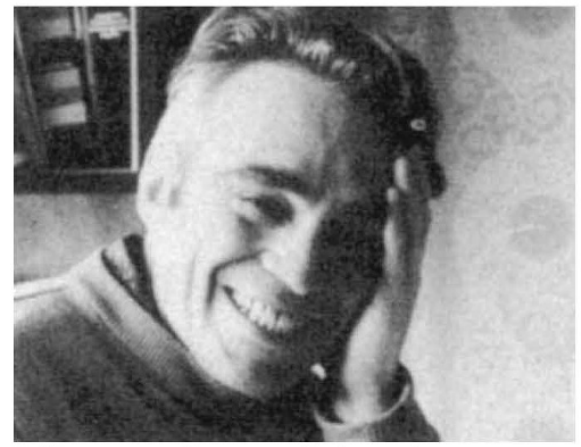

Ioffe - managing to smile through.

The letter drew attention to the position of refusnik scientists prevented from emigrating from the Soviet Union to Israel, and yet, while in the Soviet Union, deprived of any real possibility of continuing their professional activity. They noted the many efforts on their behalf by the world scientific community, and called on WFSW to join these efforts.

Following the appearance of the letter, four out of the nine signatories reported further harassment: Victor Fulmacht was told that the refusal of his emigration visa was "final" and that further applications would not be considered; Dr Mikhail Kholmyansky was summoned to the Moscow Public Prosecutor's Office and interrogated about the letter in Nature; and Klotz was similarly interrogated, in his case by the KGB, which wished to know who had written the text and under what circumstances. The administrations of the institutes where Ioffe and Klotz are employed inaugurated procedures which seemed aimed at their dismissal. For a time, Ioffe's salary was withheld, without legal justification.

Contacted last week, Legay said he was unaware of the appearance of the letter in Nature. After reading it, he said that he took exception to one expression in it: the exhortation to WFSW to "join" the efforts on behalf of the refusniks. WFSW, he said, has for many years worked vigorously for the rights of scientists - he instanced its work for Argentinians and the victims of West German Berufsverbot, and reiterated his willingness to help the refusniks. But WFSW, he said, could only work within its constitution, that is, by

\section{Washington} in its research phase. er some sort of phased deployment. officially nothing has changed. behind-the-scenes "quiet diplomacy".

As for the aborted meeting in Moscow, Legay explained that after the refusniks had been prevented from meeting him in his hotel, they had telephoned him to suggest another appointment elsewhere. But this was impossible, he said, because of his position as president of WFSW. Not only did he have no time during the general assembly to go off to such a meeting; it was also "undesirable" for someone in his position to do so.

\title{
Pressure for SDI deployment increases in United States
}

The Strategic Defense Initiative (SDI), President Reagan's plan to erect a "peace shield" against ballistic missiles over the United States, could become a reality by the middle of the $1990 \mathrm{~s}$, although it is still

Various reasons are given for this new impetus, with congressional unwillingness to spend large sums on the research programme conspicuous among them. Last year the administration saw its $\$ 5,400 \mathrm{mil}$ lion SDI budget request cut to $\$ 3,530$ million. The administration is seeking $\$ 5,800$ million for the programme this year, but observers doubt whether much more than $\$ 3.5$ million will be forthcoming. Senator Dan Quayle (Republican, Indiana), a staunch supporter of SDI, believes Congress is losing patience with SDI research, and has urged the White House to consid-

According to press reports, that is just what it is doing. A meeting apparently took place last month where alternatives were presented to President Reagan. But

Different schemes have been proposed to phase in SDI. On one, developed by the George C. Marshall Institute, a decision would be made this year to permit an initial phase to be deployed by 1992 . The first step, according to the Marshall Institute plan, would be a rapid deployment of an Exoatmosphere Re-entry Vehicle Interceptor Subsystem (ERIS). Together with a boost phase defence based on SpaceBased Kinetic Kill Vehicles (SBKKV), and a terminal phase using the High Endoatmospheric Defense Interceptor
Boost Phase Space-Based Kinetic Kill Vehicles (SBKKV)

Midcourse Phase

Exoatmosphere Re-entry Vehicle Interceptor Subsystem (ERIS)

Terminal Phase High Endoatmospheric Defense Interceptor (HEDI)
(HEDI), the report concludes that a threetiered system could be in place by 1994 .

To achieve 93 per cent effectiveness against a Soviet launch force of 1,200 Inter-Continental Ballistic Missiles (ICBMs), 11,200 warheads and 90,000 decoys, the report calculates that 11,000 SBKKVs, 10,000 ERIS interceptors and 3,000 HEDI interceptors would be needed. The effectiveness would increase to 99 per cent if the ERIS layer were assumed to be able to identify decoys. The authors of the report say a fully operational system would cost $\$ 121,000$ million.

But Richard Garwin of IBM's Thomas J. Watson Research Center, a critic of SDI, is unimpressed with the institute's plan. He feels the report is optimistic, both in the numbers of Soviet decoys and the effectiveness of the SDI defences.

Secretary of Defense Caspar Weinberger was repeatedly questioned last week about the administration's plans for SDI. In a speech at the National Press Club, he said the administration was exploring four or five ways of deploying SDI but was not committed to a firm timetable. Weinberger said he did not think a partial deployment of SDI would harm chances for an arms control agreement at the talks now in progress in Geneva, taking the view that progress on SDI gives the Soviet Union an incentive to agree to arms control.

The Soviet Union has so far shown no sign of changing its position on SDI. H. Allen Holmes, assistant Secretary of State for politico-military affairs, says the Soviet Union is still formally insisting that SDI should be only a laboratory project. Joseph Palca 